\title{
Yoğun Bakım ve Palyatif Bakım Ünitelerinde Çalışan Hemşirelerin Sürekli Öfke ve Öfke İfade Tarzları ile Bakım Davranışları Arasındaki İlişski
}

\author{
Relation Between The Trait Anger and Anger Expression Styles of The Nurses \\ Working in Intensive Care and Palliative Care Units
}

\author{
Vildan KOCATEPE ${ }^{1}$, Esra UĞUR², Ükke KARABACAK ${ }^{3}$
}

\begin{tabular}{l} 
İletişim/ Correspondence: Vildan KOCATEPE Adres/Address: Acıbadem Üniversitesi, Sağlık Bilimleri Fakültesi, Hemşirelik Bölümü, Kerem \\
Aydınlar Kampüsü Kayışdağı Cad. No:32, 34752 Ataşehir/İstanbul, Tel: 02165004465 Fax: 02165765076 E-mail: vildan.kocatepe@acibadem.edu.tr \\
\hline
\end{tabular}

\section{$\ddot{O} Z$}

Amaç: Çalışma yoğun bakım ve palyatif bakım ünitelerinde çalışan hemşirelerin sürekli öfke ve öfke ifade tarzları ile bakım davranışları arasındaki ilişkiyi belirlemek amaclyla yapıldı.

Yöntem: Tanımlayıcı türdeki çalışmanın örneklemini bir eğitim araştırma hastanesi 2. ve 3. düzey yoğun bakım ve palyatif bakım ünitelerinde çalışan 64 hemşire oluşturdu. Veri toplama aracı olarak "Sürekli Öfke-Öfke Iffade Tarz Ölçeği”", "Bakım Davranışları Ölçeği-24” ve "Kişisel Tanılama Formu” kullanıldı. Verilerin analiziSPSS 15.0 paket programı kullanılarak sayı, yüzde, ortalama, standart sapma,korelasyon analizi, Kruskal Wallis Analizi, Mann Whitney U Testive t testi ile yapıld.

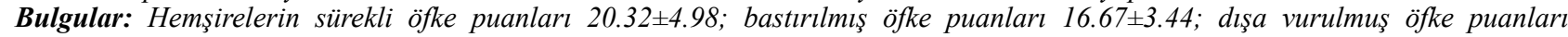

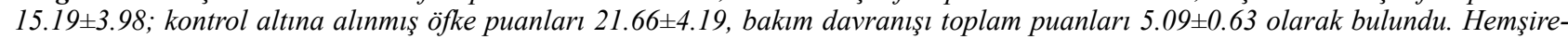
lerin sürekli öfke, bastırılmış öfke, dışa vurulmuş öfke puanları ile bakım davranışları puanları arasında anlamlı bir ilişki bulunmadı

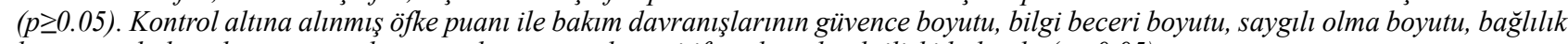
boyutu ve bakım davranışı toplam puanları arasında pozitif yönlü anlamlı iliş̧ki bulundu ( $p \leq 0.05)$.

Sonuç: Yoğun bakım ve palyatif bakım ünitelerinde hemşirelerin öfke kontrolü ve ifade tarzları hemşirelik bakım davranışlarını etkilemektedir. Bu nedenle hemşirelerin öfke kontrol becerilerini geliştirmeye yönelik programların oluşturulmasının hemşirelik bakımının kalitesini olumlu yönde etkileyeceği düşünülmektedir.

Anahtar Kelimeler: Bakım davranışı, öfke, hemşire.

\begin{abstract}
Aim: The study was conducted in order to determine the relation between the trait anger and anger expression styles and the care behaviour of the nurses working in intensive care and palliative care units.

Method: 64 nurses working in 2nd and 3nd level intensive care and palliative care units of a research and training hospital was formed the sample of the definitive study. "Trait Anger - Anger Expression Style Scales", "Caring Behaviors Inventory-24" and "Personal Identification For" were used as data collection tools. The analysis of the data was made by using the SPSS 15.0 package software with number, percentage, average, standard deviation, correlation analyses, Kruskal Walli analyses, Mann Whitney U test, t test.

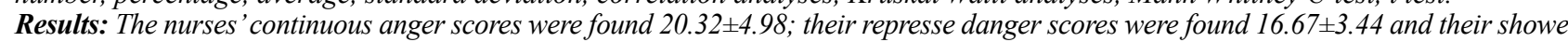
danger scores were found 15.19 \pm 3.98 . Their controlle danger scores were found $21.66 \pm 4.19$ and their care behaviour scores were found $5.09 \pm 0.63$. No meaningful relation was determined between their continuous anger, represse danger and showe danger scores and their care behaviours ( $p \geq 0.05)$. A meaningful relation in the positive direction was found between the controlle danger score and the trust dimension, knowledge and skill dimension, respect dimension and loyalty dimension of the care behaviour and the care behaviour total scores ( $p \geq 0.05$ ). Conclusion: The nurses' anger control and expression ways in intensive care and palliative care units affect their nursing care behaviour. Because of this reason, it is thought that forming programs for developing the anger control skills of the nurses in intensive care and palliative care units will affect the nursing care positively.
\end{abstract}

Keywords: Caring behaviour, anger, nurse.

7. Ulusal Yoğun Bakım Hemşireliği Kongresi'nde sözel bildiri olarak sunulmuştur (24-27 Mart 2016, Kıbrıs), 'Öğr. Gör. Acıbadem Üniversitesi, Sağllk Bilimleri Fakültesi, Hemşirelik Bölümü, İstanbul/ TURKEY, ${ }^{2} Y r d$. Doç. Dr. Acrbadem Üniversitesi, Sağllk Bilimleri Fakültesi, Hemşirelik Bölümü, İstanbul/ TURKEY, ${ }^{3}$ Doç. Dr. Acıbadem Üniversitesi, Sağlık Bilimleri Fakültesi, Hemşirelik Bölümü, İstanbul/ TURKEY

Yazının gönderilme tarihi: 18.08.2016

Yazının basım için kabul tarihi: 12.01 .2017

doi: 10.17672/fnhd.99572 


\section{GíRiş}

Bakım, hemşirelik uygulamasının temelinde yer almakta ve sağlık alanında önemi gittikçe artmaktadır (MadenoğluKıvanç 2012). Bakım hizmetini veren hemşirenin kişilik özellikleri, profesyonel tutumu, bilgi ve becerilerini sunma biçimi, hastanın bakım kalitesini dolayısıyla hasta memnuniyetini etkileyen önemli faktörlerdendir (Y1lmaz 2001). İnsanın içinde bulunduğu gerginliği dışa yansıtma biçimlerinden olan öfke, stresli iş ortamında çalş̧an hemşirelerin profesyonel tutumlarını ve hemşirelik bakım davranışlarını etkileyebilir. Rosenstein ve O'Daniel (2005) hemşirelerin öfkelerini kontrol edememesi ile tıbbi hataların arttığını, güvenli ve kaliteli bakımın olumsuz etkilendiğini ve ölümlerin arttığını belirtmişlerdir.

Özellikle kritik durumdaki hastalara hizmet verilen yogun bakım ünitelerinde, hastanın uygulanan tedavi ve bakıma olumlu yanıt vermeyerek giderek kötüleşmesi, hemşirenin başarısızlık ve yetersizlik duygusuna kapılmasına ve hastaya öfkelenmesine neden olabilir. Yoğun bakımlarda iş yükü fazlalığı, personel sıkıntısı, hastaların tıbbi durumu, hasta ölümü hemşirelerin emosyonel ve fiziksel olarak zorlanmalarına neden olarak bakım kalitesini etkileyebilir (Akgöz ve ark. 2005; Pang ve Suen 2009; Nagy 1998). Palyatif bakım merkezlerinde terminal dönemdeki hastanın bakımını üstlenen hemşireler de, hasta ve ailesi gibi korku, kaygı, yadsıma, öfke, suçluluk, depresyon ve çaresizlik hissine kapılabilir. Hemşireler bu durumda hastaya öfke duyabildikleri gibi, hastanın acı çekmesini önleyemedikleri için kendilerine de öfke duyabilirler (İnci ve Öz 2012). Bu çalışmada hastanelerde hemşirelerin psikolojik olarak en yoğun strese maruz kaldıkları yoğun bakım ve palyatif bakım ünitelerinde çalışan hemşirelerin, sürekli öfke ve öfke ifade tarzları ile bakım davranışları arasındaki ilişki araştırılmıştır.

\section{YÖNTEM}

\section{Araştırmanın Tipi}

Araştırma tanımlayıcı tipte planlandı ve uygulandı.

\section{Araştırmanın Evreni ve Örneklemi}

Çalışmanın evrenini 4 Ocak 2016-4 Şubat 2016 tarihleri arasında bir eğitim araştırma hastanesi düzey-2 ve düzey-3 yoğun bakım, cerrahi yoğun bakım ve palyatif bakım ünitelerinde çalışan hemşirelerin tamamı oluşturmuştur. Örneklemini ise bu servislerde en az 6 aydır çalışan ve çalışmanın yapıldığı süreçte izinde olmayan ve servis değişikliği yapmayan, araştırmaya katılmayı kabul eden 64 hemşire oluşturmuştur.

\section{Veri Toplama Araçları ve Verilerin Toplanması}

Çalışmada veri toplama aracı olarak "Bakım Davranışları Ölçeği-24 (BDÖ-24)”, "Sürekli Öfke-Öfke Tarz Ölçeği-SÖÖTÖ” ve "Tanıtıcı Bilgiler Formu" kullanılmıştır.

Sürekli Öfke-Öfke Tarz Ölçeği-SÖÖTÖ: Spielberger ve arkadaşları tarafından 1983 yılında geliştirilmiştir. Ölçeğin Türkçe geçerlik güvenirliği Özer (1994) tarafından yapılmış olup ölçek farklı örneklem gruplarına uygulanmıştır. Özer çalışmasında sürekli öfke alt boyutu Cronbach alfa değerini 0.67 ile 0.92; öfkeyi kontrol etme alt boyutuCronbach alfa değerini 0.80- 0.90; öfkeyi dişa vurma alt boyutu alfa değerini 0.69-0.91 ve öfkeyi içte tutma alt buyutu Cronbach alfa değerini 0.58-0.76 arasında bulmuştur. 34 maddelik dört aşama11 likert tipi bir ölçektir. Sürekli öfke ve öfke ifade tarzı olmak üzere iki alt boyuttan oluşmaktadır. Öfke ifade tarzı boyutu bastırılmış öfke, dışa vurulmuş öfke, kontrol altına alınmış öfke alt gruplarından oluşmaktadır. Ölçekteki ilk on maddenin toplamı ile sürekli öfke alt ölçeği, 13, 15, 16, 20, 23, 26, 27 ve 31 no'lu maddelerin toplamı ile öfke içte alt ölçeği, 12, 17, 19, 22, 24, 29, 32 ve 33 no'lu maddelerin toplamı ile öfke dişa alt ölçeği, 11, 14, 18, 21, 25, 28, 30 ve 34 no'lu maddelerin toplamı ile öfke kontrol alt ölçeği puanları elde edilir. Ölçeğin toplamından en düşük 34, en yüksek 136 puan alınabilmektedir (Spielberger ve ark. 1983).

Bakım Davranışları Ölçeği-24 (BDÖ-24): Wolf, Giardino, Osborne ve Ambrose tarafindan 1994 y1linda Bakım Davranışları Ölçeği-42 (BDÖ-42) hemşirelik bakım sürecini değerlendirmek amacı ile tasarlanmış, 2006 yılında Bakım Davranışları Ölçeği-24 (BDÖ-24) olarak iç tutarlığında benzer sonuçlar elde edilmesiyle, kısa formu şekline dönüştürülmüştür (Wu, Larrabee ve Putman 2006). 
Yoğun Bakım ve Palyatif Bakım Ünitelerinde Çalışan Hemşirelerin Sürekli Öfke ve Öfke Iffade Tarzları ile Bakım Davranışları Arasındaki İlişki

Bakım Davranışları Ölçeği-24 formunun ülkemiz için geçerlilik ve güvenirlilik çalışması Kurşun ve Kanan (2012) tarafından yapılmıştır. Ölçek, güvence, bilgibeceri, saygılı olma ve bağl1lık olmak üzere 4 alt gruptan ve 24 maddeden oluşmaktadır. BDÖ-24'ün yanıtları için 6 puanlık likert tipi bir skala (1: Asla, 2: Hemen hemen asla, 3: Bazen, 4: Genellikle, 5: Çoğu zaman, 6: Her zaman) kullanılmaktadır. Ölçek ve her bir alt boyut için, maddelerin puanları toplanarak elde edilen puanın madde sayısına bölünmesiyle, 1-6 arasında bir puan elde edilmektedir (Kurşun ve Kanan 2012).

Tanttıcı Bilgiler Formu: Araştırmacılar tarafından hazırlanan bu formda; hemşirelere yönelik olarak yaşı, cinsiyeti, medeni ve eğitim durumu, meslekte çalışma yılı, acil servisteki çalışma yılı, çalışma koşulları ve hemşirenin yoğun bakımda sunulan bakımdan duyduğu memnuniyet ve bunu etkileyebilecek nedenlere ilişkin görüşlerini değerlendirmeye yönelik 4'ü açık uçlu, 15 soru yer almaktadır.

\section{Araştırmanın Etik Yönü}

Araştırma yapılabilmesi için Acıbadem Üniversitesi Tıbbi Araştırmalar Değerlendirme Komisyonu'ndan yazılı etik kurul izni, araştırmanın yapıldığı hastanenin bağlı olduğu Kamu Hastaneler Birliği Genel
Sekreterliği'nden yazılı kurum izni alınmıştır. Araştırmanın örneklemini oluşturan hemşirelere çalışmanın amacı, süresi ve kendilerinden ne beklenildiği açıklanarak isteklilik, gönüllülük ilkesi doğrultusunda bilgilendirilmiş izinleri alınmıştır.

\section{Verilerin Değerlendirilmesi}

Verilerin analizi SPSS 15.0 paket programı kullanılarak say1, yüzde, ortalama, standart sapma, korelasyon analizi, Kruskal Wallis analizi, Mann Whitney U testi ve $\mathrm{t}$ testi ile yapılmıştır.

\section{BULGULAR}

Çalışmaya katılan 64 hemşirenin yarıdan fazlası (\%54.7) 21-25 yaş grubu içerisindedir. Hemşirelerin \%81.2'si kadın ve \%75'i bekardır. Hemşirelerin \%64.1'i lisans mezunudur. Çalışmaya katılan hemşirelerin \%92.2'si yoğun bakımlarda, \% 7.8'i palyatif bakımda çalışmaktadır. Hemşirelerin çoğunun (\%54.7) meslekte çalışma yılı 1-5 yıl arasındadır. Hemşirelerin \%48.4'nün yoğun bakım/ palyatif bakım ünitesinde çalışma süresi bir yıldan azdır.

Tablo 1'de belirtildiği gibi hemşirelerin sürekli öfke puan ortalamaları $20.32 \pm 4.98$; bastırılmış öfke puan ortalamaları 16.67 \pm 3.44 ; dişa vurulmuş öfke puan ortalamaları 15.19 \pm 3.98 ; kontrol altına alınmış öfke puan

Tablo 1. Hemşirelerin Sürekli Öfke ve Öfke İfade Tarz Ölçeği ile Bakım Davranışları Ölçeği Puan Ortalamaları $(\mathrm{N}=64)$

\begin{tabular}{|l|c|c|c|}
\hline Öfke Ölçeği & Min (min*) & Max (max**) & Ortalama SD \\
\hline Sürekli Öfke & $12(10)$ & $32(40)$ & $20.32 \pm 4.98$ \\
\hline Bastırılmış Öfke & $10(8)$ & $25(32)$ & $16.67 \pm 3.44$ \\
\hline Dışa Vurulmuş Öfke & $9(8)$ & $24(32)$ & $15.19 \pm 3.98$ \\
\hline Kontrol Altına Alınmış Öfke & $12(8)$ & $32(32)$ & $21.66 \pm 4.19$ \\
\hline Bakım Davranışları Ölçeği-24 & Min (min*) & Max (max**) & Ortalama SD \\
\hline Güvence Boyutu & $2.5(1)$ & $6(6)$ & $5.05 \pm 0.76$ \\
\hline Bilgi Beceri Boyutu & $2.6(1)$ & $6(6)$ & $5.26 \pm 0.66$ \\
\hline Saygılı Olma Boyutu & $2.5(1)$ & $6(6)$ & $5.14 \pm 0.69$ \\
\hline Bağlılık Boyutu & $2.2(1)$ & $6(6)$ & $4.94 \pm 0.74$ \\
\hline Bakım Davranışı Toplam Puanı & $2.24(1)$ & $6(6)$ & $5.09 \pm 0.63$ \\
\hline *Ölçekten alınabilecek Min puan & & \\
\hline **ölçekten alınabilecek Max puan & & \\
\hline
\end{tabular}


ortalamaları 21.66 \pm 4.19 'dur. Hemşirelerin bakım davranışları güvence boyutu puan ortalamaları 5.05 \pm 0.76 ; bilgi beceri boyutu puan ortalamaları $5.26 \pm 0.66$; saygil olma boyutu puan ortalamaları $5.14 \pm 0.69$; bağlılık boyutu puan ortalamaları 4.94 \pm 0.74 ; bakım davranışı toplam puan ortalamaları $5.09 \pm 0.63$ olarak bulunmuştur.
Tablo 2'de hemşirelerin uygulanan hemşirelik bak1mını yeterli bulma durumlarının, bakım davranışları ölçeği alt boyutlarından sadece saygılı olma boyutunu etkilediği bulunmuştur ( $>00.05$ ). Uygulanan hemşirelik bakımını yeterli bulan hemşirelerin, saygılı olma alt boyutunda en yüksek puan ortalamasını aldığı saptan-

Tablo 2. Hemşirelerin Yapılan Hemşirelik Bakıma İlişkin Görüşleri ile Bakım Davranışları Ölçeği Puan Ortalamaları (N=64)

\begin{tabular}{|c|c|c|c|c|c|c|}
\hline & & \multicolumn{5}{|c|}{ Bakım Davranışları Puan Ortalamaları } \\
\hline & $\mathbf{N}(\%)$ & $\begin{array}{r}\text { Güvence Boyutu } \\
\mathrm{X} \pm \mathrm{SS}\end{array}$ & $\begin{array}{r}\text { Bilgi Beceri } \\
\text { Boyutu } \\
\mathbf{X} \pm \mathbf{S S}\end{array}$ & $\begin{array}{r}\text { Saygilı } \\
\text { Olma } \\
\text { Boyutu } \\
\mathrm{X} \pm \text { SS }\end{array}$ & $\begin{array}{r}\text { Bağlılık } \\
\text { Boyutu } \\
\text { X } \pm \text { SS }\end{array}$ & $\begin{array}{r}\text { Bakım } \\
\text { Davranışı } \\
\text { Toplam } \\
\text { Puanı } \\
\mathrm{X} \pm \mathrm{SS}\end{array}$ \\
\hline \multicolumn{7}{|c|}{ Yoğun bakım/ palyatif bakımda uygulanan hemşirelik bakımını yeterli bulma } \\
\hline Evet & $4(6)$ & $5.50 \pm 0.67$ & $5.65 \pm 0.44$ & $5.79 \pm 0.41$ & $5.60 \pm 0.54$ & $5.64 \pm 0.52$ \\
\hline Kismen & 53(83) & $5.00 \pm 0.78$ & $5.23 \pm 0.66$ & $5.14 \pm 0.67$ & $4.91 \pm 0.68$ & $5.07 \pm 0.61$ \\
\hline Hayır & $7(11)$ & $5.17 \pm 0.64$ & $5.26 \pm 0.73$ & $4.73 \pm 0.79$ & $4.77 \pm 1.13$ & $4.99 \pm 757$ \\
\hline \multicolumn{2}{|l|}{ KW değeri } & 1.952 & 1.755 & 6.641 & 3.704 & 3.76 \\
\hline \multicolumn{2}{|l|}{ p değeri } & 0.377 & 0.416 & 0.036* & 0.157 & 0.153 \\
\hline \multicolumn{7}{|c|}{ Hasta bakımı dışında iş yükünün fazla olması } \\
\hline Evet & 54(84) & $5.50 \pm 0.68$ & $5.65 \pm 0.44$ & $5.79 \pm 0.42$ & $5.60 \pm 0.54$ & $5.63 \pm 0.52$ \\
\hline Hayır & 10(16) & $5.00 \pm 0.78$ & $5.23 \pm 0.66$ & $5.14 \pm 0.68$ & $4.91 \pm 0.68$ & $5.07 \pm 0.61$ \\
\hline \multicolumn{2}{|l|}{ Mann Whitney U değeri } & 195.000 & 264.500 & 236.000 & 237.000 & 238.000 \\
\hline \multicolumn{2}{|l|}{ P değeri } & 0.164 & 0.918 & 0.527 & 0.540 & 0.554 \\
\hline \multicolumn{7}{|c|}{ Hemşire başına düşen hasta sayısının fazla olması } \\
\hline Evet & 36(56) & $5.02 \pm 0.68$ & $5.29 \pm 0.59$ & $5.12 \pm 0.71$ & $4.91 \pm 0.74$ & $5.08 \pm 0.59$ \\
\hline Hayır & $28(44)$ & $5.10 \pm 0.87$ & $5.20 \pm 0.74$ & $5.15 \pm 0.70$ & $4.99 \pm 0.77$ & $5.11 \pm 0.68$ \\
\hline \multicolumn{2}{|l|}{ Mann Whitney U değeri } & 427.500 & 485.500 & 491.500 & 458.000 & 470.500 \\
\hline \multicolumn{2}{|l|}{ P değeri } & 0.299 & 0.801 & 0.865 & 0.532 & 0.650 \\
\hline \multicolumn{7}{|c|}{ Serviste yeterli hemşire sayısının bulunmaması } \\
\hline Evet & $36(56)$ & $5.11 \pm 0.68$ & $5.31 \pm 0.57$ & $5.08 \pm 0.70$ & $4.87 \pm 0.73$ & $5.09 \pm 0.58$ \\
\hline Hayır & 28(44) & $4.97 \pm 0.85$ & $5.19 \pm 0.75$ & $5.20 \pm 0.69$ & $5.03 \pm 0.75$ & $5.10 \pm 0.69$ \\
\hline \multicolumn{2}{|l|}{ Mann Whitney U değeri } & 463.500 & 478.500 & 436.000 & 410.000 & 473.500 \\
\hline \multicolumn{2}{|l|}{ P değeri } & 0.538 & 0.728 & 0.355 & 0.201 & 0.680 \\
\hline \multicolumn{7}{|c|}{ Bakım için yeterli zamanın olmaması } \\
\hline Evet & $31(48)$ & $5.00 \pm 0.70$ & $5.19 \pm 0.61$ & $5.04 \pm 0.70$ & $4.85 \pm 0.73$ & $5.02 \pm 0.58$ \\
\hline Hayır & 33(52) & $5.09 \pm 0.72$ & $5.31 \pm 0.70$ & $5.22 \pm 0.68$ & $5.03 \pm 0.75$ & $5.16 \pm 0.67$ \\
\hline \multicolumn{2}{|l|}{ t değeri } & -0.491 & -0.737 & -0.996 & -0.960 & -0.901 \\
\hline \multicolumn{2}{|l|}{$P$ değeri } & 0.625 & 0.464 & 0.323 & 0.341 & 0.371 \\
\hline \multicolumn{7}{|c|}{ Hemşirelerin yoğun bakım/ palyatif bakım ünitesinde isteyerek çalışmaması } \\
\hline Evet & 21(33) & $5.10 \pm 0.63$ & $5.07 \pm 0.60$ & $5.10 \pm 0.78$ & $4.89 \pm 0.81$ & $5.04 \pm 0.63$ \\
\hline Hayır & $43(67)$ & $5.02 \pm 0.82$ & $5.34 \pm 0.66$ & $5.15 \pm 0.65$ & $4.96 \pm 0.71$ & $5.12 \pm 0.63$ \\
\hline \multicolumn{2}{|l|}{ Mann Whitney U değeri } & 445.500 & 322.000 & 447.500 & 433.500 & 407.500 \\
\hline \multicolumn{2}{|l|}{ P değeri } & 0.931 & 0.062 & 0.954 & 0.796 & 0.529 \\
\hline
\end{tabular}


Yoğun Bakım ve Palyatif Bakım Ünitelerinde Çalışan Hemşirelerin Sürekli Öfke ve Öfke Iffade Tarzları ile Bakım Davranışları Arasındaki İlişki

Tablo 3. Hemşirelerin Sürekli Öfke ve Öfke İfade Tarz Ölçeği ile Bakım Davranışları Ölçeği Puan Ortalamaları Arasındaki İlişki

\begin{tabular}{|l|r|r|r|r|r|}
\hline & $\begin{array}{r}\text { Güvence } \\
\text { Boyutu } \\
\mathbf{r} / \mathbf{p}\end{array}$ & $\begin{array}{r}\text { Bilgi Beceri } \\
\text { Boyutu } \\
\mathbf{r} / \mathbf{p}\end{array}$ & $\begin{array}{r}\text { Saygııl Olma } \\
\text { Boyutu } \\
\mathbf{r} / \mathbf{p}\end{array}$ & $\begin{array}{r}\text { Bağlılık } \\
\text { Boyutu } \\
\mathbf{r} / \mathbf{p}\end{array}$ & $\begin{array}{r}\text { Bakım } \\
\text { Davranışı } \\
\text { Toplam Puanı } \\
\mathbf{r} / \mathbf{p}\end{array}$ \\
\hline Sürekli Öfke & $-.026 / .841$ & $-.149 / .240$ & $-.113 / .372$ & $-.049 / .700$ & $-.093 / .467$ \\
\hline Bastırılmıs̆ Öfke & $.005 / .968$ & $.035 / .784$ & $.035 / .786$ & $.042 / .740$ & $.033 / .797$ \\
\hline Dişa Vurulmuş Öfke & $.108 / .395$ & $-.011 / .929$ & $.038 / .765$ & $.056 / .660$ & $.057 / .655$ \\
\hline Kontrol Altına Alınmış Öfke & $.284 / .023^{*}$ & $.329 / .008^{*}$ & $.317 / .011^{*}$ & $.282 / .024^{*}$ & $.344 / .005^{*}$ \\
\hline$* \mathrm{p} \leq 0.05$ & \multicolumn{3}{|l|}{} \\
\hline
\end{tabular}

mıştır (5.79 \pm 0.41$)$. Hemşirelerin hasta bakımı dışında iş yükünün fazla olması, hemşire başına düşen hasta sayısının fazla olması, serviste yeterli hemşire sayısının bulunmaması, bakım için yeterli zamanı olmaması, hemşirelerin yoğun bakım/ palyatif bakım ünitesinde isteyerek çalışma durumu ile bakım davranışları ölçeği alt boyutları ve toplam bakım davranışı puan ortalamaları arasında anlamlı bir fark bulunamamıştır.

Hemşirelerin sürekli öfke, bastırılmış öfke, dışa vurulmuş öfke puan ortalamaları ile bakım davranışları puan ortalamaları arasında anlamlı bir ilişki bulunamamıştır ( $p>0.05$ ) (Tablo 3). Sürekli öfke ve öfke tarz ifade ölçeğinin, kontrol altına alınmış öfke alt puanı ile bakım davranışları ölçeğinin tüm alt boyutları ve bakım davranışı toplam puanı arasında pozitif yönlü anlamlı bir ilişki bulunmuştur ( $\mathrm{p} \leq 0.05)$.

\section{TARTIŞMA}

Sağlık bakımının önemli bir parçası olan hemşirelik, uygulama alanında birçok konuda hasta için en doğru karar1 verip, kaliteli ve güvenli bakım hizmeti sunmay1 gerektirir. Yoğun bakım ve palyatif bakım gibi özellikli ünitelerdeki hastaların iyileşme sürecinde, hemşirelik bakımının çok önemli bir yeri bulunmaktadır (Terzi ve Kaya 2011).

Profesyonel bakımın bilişsel, duyuşsal ve psikomotor becerilerle birlikte ve her bireyin eşsiz ve kendine özgü özelliklere sahip olduğu anlayışı doğrultusunda bütüncül bir yaklaşımla sunulması gereklidir (Dinç 2009). Çalışmada hemşirelerin bakım davranışı puan ortalamaları incelendiğinde, en yüksek puan ortalama- sını bilgi beceri alt boyutu (5.26 \pm 0.66$)$ en düşük puan

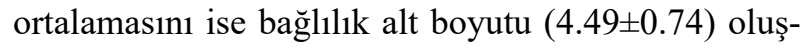
turmaktadır. Benzer şekilde literatürde farklı birimlerde çalışan hemşirelerle yapılan çalışmalarda da hemşirelerin en yüksek puanı bilgi beceri alt boyutunda, en düşük puanı bağlılık alt boyutunda aldığı görülmüşsür (Aydın 2013; Göğüş 2016; He ve ark. 2013; Karlou, Papathanassoglou ve Patiraki 2015; Kurşun 2010; Papastavrou ve ark. 2011). Bunun nedeni çalışmamızda ve Türkiye'de yapılan diğer çalışmalarda hemşirelerin yarıdan fazlasının meslekteki yıllarının en az 1-5 yıl içinde olması ve çoğunun en az lisans programlarından mezun olmasının bilgi ve beceri puanlarını arttırdığ1 söylenebilir (Aydın 2013; Gögüşs 2016; Kurşun ve Kanan 2012).

Hemşirelik bakımının yeterli ve nitelikli olması, sağlık politikaları, sağlığa ayrılan kaynakların dağılımı, hizmetin sunulduğu kuruma ait örgütsel işleyiş, iletişim gibi faktörlerden etkilenmektedir (Dinç 2010). Çalışmada hemşirelerin uygulanan hemşirelik bakımını yeterli bulma durumlarının bakım davranışlarından sadece saygılı olma alt boyutunu etkilediği, diğer bakım davranışı puan ortalamalarını etkilemediği görülmüştür. Göğüş (2016)'ün cerrahi servisi hemşireleri ile yaptığı çalışmada da hemşirelerin serviste uygulanan hemşirelik bakımını yeterli bulma durumunun bakım davranışı puan ortalamalarını etkilemediği görülürken; Kurşun (2010) ve Aydın (2013)'ın çalışmalarında hemşirelik bakımını yeterli bulan hemşirelerin puan ortalamaları, bulmayanlara göre daha anlamlı olarak yüksek bulunmuştur. 
ICN (International Council of Nurses) 2006 y1li raporunda güvenli hemşire istihdamının önemini vurgulamıştır. Rapora göre, yeterli istihdam ve personel arasında iyi görev dağılımının hasta sonuçlarında iyileşme yaptığ1 ve istenmeyen olayları azalttığı belirtilmektedir. $\mathrm{Bu}$ nedenle birimlerde yeterli hemşire bulunmadığı ve hemşire başına düşen hasta sayısının düzenlenmediği ya da hemşirenin biriminde isteyerek çalışmadığı durumlarda hastaya verilen bakım kalitesi azalmaktadır (ICN 2006).

Literatürde hemşire sayısındaki yetersizliğin, çalışma koşullarının, iletişim sorunlarının, görevi olmayan uygulamaların yapılmasının, iş yükünün fazla olmasının hemşirelik bakımını etkilediği belirtilmektedir (Göçmen 2010; Karadağ ve Taşçı 2005). Bu çalışmada ise hemşirelerin hasta bakımı dışındaki iş yükünün fazla olması, serviste yeterli hemşire sayısının bulunmamas1, bakım için yeterli zamanının bulunmaması bakım davranışları alt boyut puanlarını ve toplam bakım davranış puanlarını etkilemediği belirlenmiş̦tir.

Çalışmada, hemşire başına düşen hasta sayısının fazla olması ile bakım davranışları puanları arasında anlamlı bir fark bulunmamıştır. Ancak Kurşun, hemşire başına düşen yatak sayısının bakım davranışlarından güvence, saygılı olma ve bağlılığı etkilediğini belirtmiştir. Sağlık Bakanlığı'nın yayınladığı Türkiye'de Sağlık Eğitimi ve Sağlık İnsan Gücü Durum Raporuna (2014) göre Avrupa ülkelerinde 100.000 kişiye düşen hemşire sayısı ortalama 836 iken, Türkiye' de bu sayı 197'ye kadar düşmektedir. Bir yoğun bakımda yapılan çalışmada yetiştirmeleri gereken iş yükünü zamanında yetiştiremeyen hemşirelerin örgütsel rahatsızlık ve iş stresleri daha fazla bulunmuştur (Dede ve Çınar 2008).

Hemşirelerin bulunduğu kliniklerde isteyerek çalışmasının hemşirelerin iş doyumunu etkilediği düşünülmektedir. Sevdiği birimde çalışan hemşirenin iş doyumu artacak, dolayısıyla hemşirelik mesleğindeki verimliliği ve sağlık hizmetinin kalitesi artacaktır (Çam ve Yıldırım 2010). Hemşirelerin yoğun bakım/ palyatif bakım ünitelerinde isteyerek çalışma durumlarının bakım davranışları alt boyut puanlarını ve toplam bakım davranış puanlarını etkilemediği görülmüştür. Çalışma sonuçları Aydın (2013)'ın acil servis hemşireleri ile yaptığı çalışma sonuçları ile benzerdir. Ancak Kurşun (2010)'un çalışmasında genel cerrahi servisinde isteyerek çalışan bireylerin bakım davranışları tüm alt boyut puanları ve toplam bakım davranış puanları anlamlı olarak yüksek çıkmıştır.

Yoğun bakım hemşireleri yaşamı tehdit edici kriz durumları, karmaşık teknoloji, acil karar verme sorumluluğu, aşırı uyarıcı çevre, hareketlilik ve gürültünün fazla olması gibi stresörlerden etkilenmektedirler (Akbal, Özer ve Baltaş 2001). Bu durum hemşirelerin öfke yaşamasına sebep olabilmektedir. Rosenstein ve O’Daniel (2005) yaptığ 1 çalışmada hemşirelerin öfkelendiklerinde ekip içi iletişimde sorunlar yaşadıklarını, hasta hakkında bilgi alışverişiyle ilgili aksaklıklar olduğunu bulmuşlardır. Çalışmamızda hemşirelerin en yüksek puan ortalamasını kontrol altına alınmış öfke boyutu (21.66 \pm 4.19$)$ en düşük puan ortalamasını ise dişa vurulmuş öfke boyutu (15.19 \pm 3.98$)$ oluşturmaktadır. Hemşirelik öğrencileri ile yapılan bir araştırma sonucu da bizim çalışmamız ile benzer olarak kontrol altına alınmış öfke puanı en yüksek çıkmış ve sebebi hemşirenin yoğun çalışma temposuna karşın sahip olduğu mesleki felsefe ve değerler ile ilgili olabileceği şeklinde açıklanmıştır (Kaya ve ark. 2012).

Çalışmada hemşirelerin kontrol altına alınmış öfke puanı ile bakım davranışları puan ortalamaları arasında anlamlı bir ilişki bulunmuştur. Hemşirelerin kontrol altına alınmış öfke puanı dışında puan ortalamalarının ölçek puan ortalamalarına yakın olması nedeniyle, bakım davranışlarını fazla etkilemediği düşünülmektedir. Çalışmadaki hemşirelerin yaşının, toplam hemşirelik deneyim sürelerinin az olması öfke düzeylerinin artmamasına, dolayısıyla bakım davranışları ile arasında anlamlı bir ilişki olmamasına sebep olmuş olabilir. Kontrol altına alınmış öfke puanı arttıkça tüm bakım davranışları puan ortalamaları artmaktadır. Benzer şekilde psikiyatri hemşireleri ile yapılan bir çalışmada da, kontrol altına alınmış öfke puanları ile iş motivasyonu arasında pozitif yönlü anlamlı bir ilişki bulunmuş ve sonuçta iş motivasyonunun artmasının 
Yoğun Bakım ve Palyatif Bakım Ünitelerinde Çalışan Hemşirelerin Sürekli Öfke ve Öfke Ífade Tarzları ile Bakım Davranışları Arasındaki İlişki

hemşirelik bakımına yansıyacağı belirtilmiştir (Engin ve Cam 2006). Bayrı ve Kelleci (2009)'nin hemşirelerle yaptığı çalışmada genel sağlık anketi puanları ile öfke puanları arasındaki ilişkide dışa vurulmuş ve kontrol altına alınmış öfke puanlarının azaldıkça psikolojik sağlık durumlarının bozulduğu bulunmuştur. Öfke kontrolü ve bunu sağlayan stratejilerdeki amaç, öfkenin yol açtı̆̆ duygusal ve fizyolojik tepkileri azaltabilmektir. Bu konudaki doğru yaklaşım, insanlar ya da olaylar karşısında gösterilen içsel ve dışsal tepkileri kontrol edebilmek, onları yapıcı bir şekilde yönetebilmektir (Kaya ve Solmaz 2009). Hemşirenin öfkesini kontrol etmesi bakım davranışlarında kaliteyi arttıracaktır.

\section{SONUÇ VE ÖNERÍLER}

Hemşirelik bakım kalitesi hemşirenin bakım davranışları ile ilgilidir. Bakım davranışları hemşirenin sosyo-demografik özelliklerinden etkilenebilir. Öfke de hemşirelik bakımını etkileyen özelliklerden biridir. Hemşirenin öfkesini kontrol edebilmesi, hemşirelik bakım davranışlarını olumlu yönde etkileyerek bakım kalitesini arttırmaya katkı sağlayacaktır. Yoğun bakım ve palyatif bakım ünitelerinde de hemşirelerin öfke kontrolü ve ifade tarzları hemşirelik bakım davranışlarını etkilemektedir. Bu nedenle hemşirelerin öfke kontrolüne yönelik güçlendirilmeleri gerekmektedir. Öfke kontrolünün geliştirilmesine yönelik kurumsal programlar düzenlenebilir ve hemşireler bu programlara yönlendirilebilir. Diğer yandan hemşirelerin öfke düzeyini etkileyen dış faktörlerden olan iş ortamında da öfke düzeylerini arttıracak örgütsel faktörlerin azaltılmasına yönelik, yönetimsel düzeyde düzenlemeler yapılmalıdır.

\section{KAYNAKLAR}

Akbal-Ergün, Y., Özer, Y., Baltaş, Z. (2001). Yoğun bakımda çalışan hemşirelerin stres düzeyleri ve stresin hemşireler üzerindeki etkileri. Yoğun Bakım Hemşireleri Dergisi, 5(2): 70-79.

Akgöz, S. ve ark. (2005). Uludağ Üniversitesi Sağlık Uygulama ve Araştırma Merkezi'nde çalışan hemşirelerin mesleki doyumları. Türkiye Klinikleri Journal of MedicalEthics, 13(2): 86-96.

Aydın, H. (2013). Acil serviste hasta ve hemşirelerin bakım davranışlarının değerlendirilmesi. Yayınlanmamış Yüksek Lisans Tezi, Marmara Üniversitesi Sağlık Bilimleri Enstitüsü, İstanbul.
Bayrı, F., Kelleci, M. (2009). Hemşirelerin sürekli öfke ve öfke ifade tarzları ile genel sağlık durumları arasındaki ilişki. Türkiye Klinikleri J NursSci, 1(2): 65-70.

Çam, O., Yıldırım, S. (2010). Hemşirelerde iş doyumu ve etkileyen faktörler. Turkiye Klinikleri J Nurs, 2(1): 64-70.

Dede, M., Çınar, S. (2008). Dahiliye yoğun bakım hemşirelerinin karşılaştıkları güçlükler ve iş doyumlarının belirlenmesi. Maltepe Üniversitesi Hemşirelik Bilim ve Sanatı Dergisi, 1(1): 3-14.

Dinç, L. (2009). Hemşirelik hizmetlerinde etik yükümlülükler. Hacettepe Tip Dergisi, 40: 113-119.

Dinç, L. (2010). Bakım kavramı ve ahlaki boyutu. Sağllk Bilimleri Fakültesi Hemşirelik Dergisi, 17(2): 74-82.

Engin, E., Cam, O. (2006). Correlation between psychiatric nurses' anger and job motivation. Archives of PsychiatricNursing, 20(6): 268-275.

Göçmen, Z. (2010). Hemşirelik bakımında hemşirenin mesleki özerkliğinin değerlendirilmesi: Niteliksel bir çalışma. Yayınlanmamış Doktora Tezi, Ankara Üniversitesi Sağlık Bilimleri Fakültesi, Ankara.

Göğüş, F. (2016). Cerrahi hastaların ve cerrahi hemşirelerinin bakım davranışı değerlendirmelerinin karşılaştırılması. Yayınlanmamış Yüksek Lisans Tezi, Ankara Üniversitesi Sağlık Bilimleri Enstitüsü, Ankara.

International Council of Nurses (ICN) (2006). The ICN Code of Ethics for Nurses, http://www.icn.ch/who-we-are/code-of-ethicsfor-nurses/ (12.08.2016).

İnci, F., Öz, F. (2012). Palyatif bakım ve ölüm kaygısı. Psikiyatride Güncel Yaklaşımlar-CurrentApproaches in Psychiatry, 4(2): 178187.

He, T. ve ark. (2013). Perceptions of caring in China: Patient and nurse questionnaire survey. International Nursing Review. 60(4): 487-493.

Karadağ, S., Taşçı, S. (2005). Kayseri Devlet Hastanesi'nde çalı̧̧an hemşirelerin verdiği hemşirelik bakımı ve bakımı etkileyen faktörler. Sağlık Bilimleri Dergisi (Journal of Health Sciences), 14(Ek Sayı: Hemşirelik Özel Sayısı): 13-21.

Karlou, C., Papathanassoglou, E., Patiraki, E. (2015). Caring behaviours in cancer care in Greece. Comparison of patients', their care givers' and nurses' perceptions. European Journal of Oncology Nursing, 19(3): 244-250.

Kaya, N. (2012). Hemşirelik ve ebelik öğrencilerinin öfke ve yalnızlık özellikleri. Hemşirelikte Eğitim ve Araştırma Dergisi, 9(2): 18-26.

Kaya, N., Solmaz, Ş. (2009). Bir üniversite hastanesinin kulak burun boğaz kliniğinde çalışan hemşirelerin öfke ve öfke ifadesi. Turkiye Klinikleri J Nurs Sci, 1(2): 56-64. 
Kurşun, Ş. (2010). Genel cerrahi servisinde hasta ve hemşireler tarafından hemşirelik bakım kalitesinin algılanması. Yayınlanmamış Doktora Tezi. İstanbul Üniversitesi Sağlık Bilimleri Enstitüsü, İstanbul.

Kurşun, Ş., Kanan, N. (2012). Bakım davranışları ölçeği-24'ün Türkçe formunun geçerlik ve güvenirlik çalışması. Anadolu Hemşirelik ve Sağlık Bilimleri Dergisi, 15(4): 299-235.

Madenoğlu-Kıvanç, M. (2012). Hemşirelik uygulamalarında bakım kavramı. Atabek, T., Karadağ, A. (Ed.). Hemşirelik Esasları Hemşirelik Bilimi ve Sanatı. Akademi Basın ve Yayıncılık, İstanbul, 219-235.

Nagy, S. (1998). Comparison of the effects of patients' pain on nurses working in burns and neonatal intensive care units. Journal of Advanced Nursing, 27: 335-340.

Özer, A. K. (1994). Sürekli Öfke ve Öfke İfadesi Tarzı (Öfke Tarzı) Ölçekleri ön çalışması. Türk Psikoloji Dergisi, 9(31): 26-35.

Pang, P. S. K., Suen, L. K. P. (2009). Stressors in the intensive care unit: Comparing the perceptions of Chinese, patients and their family. Stress and Health, 25: 151-159.

Papastavrou, E. ve ark. (2011). A cross-cultural study of the concept of caring through behaviours: Patients' and nurses' perspectives in six different EU countries. Journal of Advanced Nursing, 68(5): 1026-1037.
Rosenstein, A. H., O’Daniel, M. (2005). Disruptive behavior and clinical outcomes: Perceptions of nurses and physicians. NursManage, 36(1): 18-29.

Spielberger, C. D. ve ark. (1983). Assessment of anger: The State Trait Anger Scale. Butcher, J. N., Spielberger, C. D. (Eds.). Advances in Personality Assessment. Volume II, LEA, Hillsdade NJ, 159-187.

Terzi, B., Kaya, N., (2011). Yoğun bakım hastasında hemşirelik bakımı. Yoğun Bakım Dergisi, 1: 21-25.

Türkiye'de Sağlık Eğitimi ve Sağlık İnsan Gücü Durum Raporu (2014). http://www.saglik.gov.tr/TR/belge/1-32644/ turkiyede-saglik-egitimi-ve-saglik-insangucu-durum-rapo-.html (15.08.2016).

Wolf, Z. R., Giardino, E. R., Osborne, P. A., Ambrose, M. S. (1994). Dimensions of nurse caring. Image J NursSch, 26(2): 107-111.

Wu, Y., Larrabee, J. H., Putman, H. P. (2006). Caring Behaviors Inventory: A reduction of the 42-item instrument. Nursing Research, 55(1): 18-25.

Yılmaz, M. (2001). Sağlık bakım kalitesinin bir ölçütü: Hasta memnuniyeti. Cumhuriyet Üniversitesi Hemşirelik Yüksekokulu Dergisi, 5(2): 69-74. 